\title{
The Influence of Parental Resources on the Timing of the Transition to Marriage
}

\author{
William G. AxinN \\ Department of Sociology and Population Research Center, The University of Chicago
}

\begin{abstract}
AND
Arland Thornton

Institute for Social Research, Department of Sociology, and Population Studies Center, The University of Michigan
\end{abstract}

This paper studies the relationship of parental resources to the marital transitions of children. It extends past research by explicitly distinguishing various dimensions of parental resources and by taking parental preferences directly into account. We test models in which parental resources have additive effects on the timing of marriage and models in which parental resources interact with parents' preferences for the timing of their children's marriages. The analysis shows that both parental financial resources and parental education influence children's marital behavior. Our analysis also demonstrates that parental preferences for their children's age at marriage do matter, but that this influence weakens as the children grow older. Finally, the analysis indicates that the effects of parents' financial resources interact with parents' preferences to affect the timing of their children's transitions to marriage. 1992 Academic Press, Inc.

The sociological study of marital timing has been a focal pursuit in both family and demographic studies throughout the history of sociology (see Malthus, 1798). In recent years intensive studies of life course events, and the implications of events in early adulthood for later life chances in particular, have focused increased attention on marital timing. The tran-

Please send all correspondence to William G. Axinn, Population Research Center, University of Chicago and NORC, 1155 East 60th St., Chicago, IL 60637-2799. This research was conducted with support from the National Institute of Child Health and Human Development. The authors acknowledge Ronald Freedman, David Goldberg, Lolagene Coombs, and Deborah Freedman for their work on the panel study analyzed here. We appreciate the assistance of the technical sections of the Survey Research Center with the collection, coding, and analysis of the data. The authors also thank Linda Young-DeMarco for assistance with data analysis and Judy Baughn for assistance with manuscript preparation. 
sition to marriage is considered one of the key events marking the transition to adulthood (Marini, 1984; Hogan, 1978). The timing of marriage influences a wide variety of other experiences, ranging from childbearing to educational attainment to divorce (Bongaarts, 1982; Marini, 1978; Thornton and Rodgers, 1987). The decades since World War II have also seen dramatic changes in marital timing in the United States (Cherlin, 1981; Rodgers and Thornton, 1985). Since the timing of this pivotal event is interwoven with the complex set of events in young adulthood (Rindfuss, 1991), changes in marital timing may have broad ranging implications for other experiences in young adulthood. A better understanding of the causes of variations in marital timing is an important step toward a more complete understanding of the role of this important young adult transition.

The theoretical and empirical literature on marriage contains numerous references to the influence of the socioeconomic environment of the parental home on the marriage timing of children. That literature identifies several reasons why children growing up in homes with a high standard of living might delay marriage. They may be less desirous of leaving their parental home, may have high consumption aspirations, and may attain more education. More recently, observers have noted that the impact of parental resources may depend on the wishes of the parents, although actual data about parental preferences have been unavailable. The argument is that parents with many resources may be able to more easily influence their children's behavior in the direction of parental preferences.

Our paper advances our knowledge of intergenerational influences on children's marriages both theoretically and empirically. Our research makes a theoretical contribution by specifying more precisely than earlier work the nature of parental resources and how different kinds of resources might impact on children's marital timing. We also specify more clearly how parental resources might interact with parental preferences to influence the behavior of children. A final theoretical contribution focuses on the ability of parents to influence children as the children mature across the life course. Empirically, our research is able to incorporate multiple measures of parental resources, a measure of parental preferences for children's behavior, and a measure of children's marital timing. This empirical advancement is possible because we have panel data collected from both mothers and children during the years the children were maturing into adulthood.

\section{CAUSAL MECHANISMS}

Social theory provides a number of causal mechanisms linking the standard of living of the parental home to children's marital behavior. One mechanism focuses on the parental home as an environment in which children live. High parental socioeconomic resources probably enhance 
parents' ability to provide their children with the material necessities and luxuries of life. High parental education may also enhance parents' ability to provide a more attractive home environment in nonmaterial ways. A utility maximizing decision-maker would be expected to want to continue residing in an environment with these material and nonmaterial advantages. Although there are many routes of leaving the parental home, marriage represents one of the most important ones. Thus, young people growing up in homes with high parental educations, income, and consumption levels may be less motivated to leave the parental home and, therefore, marry later. We examine this mechanism by testing the effects of measures of parents' incomes, assets, and educations on the timing of their children's marriages.

A second causal mechanism focuses on the parental home as a socializing agent, with children who grow up in wealthier homes having higher consumption aspirations. With higher consumption aspirations children from wealthier homes would be expected to delay marriage until they could maintain a high standard of living on their own (Easterlin, 1980). If this hypothesis is correct, individuals who come from parental homes with many resources are likely to marry later, since they will strive to attain higher levels of consumption before marrying. Tests of the influence of parents' incomes and assets also capture this mechanism.

A third mechanism focuses on the educational process and the influence of parents on that process. Parental socioeconomic status can affect children's educations by providing a better learning environment. Financial resources, likc incomc and assets, might enhance the learning environment by providing access to educational materials and experiences while resources like education may increase parents' motivation and ability to participate in their children's learning. Socioeconomic resources can also help to provide better schooling by allowing families to move to areas with good schools and by providing financial resources to finance higher education. The educational attainment of parents also influences their aspirations for their children's educational attainment (Marini, 1978), which probably influence both their children's own aspirations and their children's actual school achievement. Certainly there is ample evidence that parents' educational attainment has a positive influence on the amount of education their children attain (Sewell, Haller, and Portes, 1969; Sewell and Hauser, 1975; Sewell, Hauser, and Wolf, 1980). The influence of parental resources on children's educational attendance is important because young people who are attending school, and who have high cducational expectations, are more likely to delay their marriages (Marini, 1978; Goldscheider and Waite, 1986; Thornton, Axinn, and Teachman, 1992; Waite and Spitze, 1981). Thus, features of parental resources which act to increase children's educational aspirations and attainment also delay children's transitions to marriage. This causal mechanism predicts a de- 
laying effect of parents' incomes, assets, and educations on children's first marriages, a hypothesis we test below.

The influence of parental resources on marriage through the children's educational attainment may also change as the child passes through the life course since this mechanism is only believed to operate while children are in school. As all children complete their educations, this mechanism would likely disappear. Thus we expect a diminishing effect of parental resources on marriage through the children's educational attainment because school enrollment decreases as children age and complete their educations. We explore this hypothesis by testing the effects of an interaction term of parents' education and children's age on the timing of children's marriages.

A fourth causal mechanism focuses on the influence of parental socioeconomic status on parental attitudes toward marital timing. This perspective suggests that parental resources may influence the transition to marriage through their impact on parental attitudes towards marital timing (Modell, 1980; Waite and Spitze, 1981). Parents' resources probably affect parents' aspirations for their children's achievements in activities which may compete with marriage, such as education or careers. The more education, income, and assets parents have the more likely they are to believe their children ought to postpone marriage. The older the parents' ideal age for their children to marry, the more likely they are to urge their children to delay marriage, which will probably result in an older age at marriage.

Many scholars have found that an individual's own ideal age at marriage influences the timing of his or her eventual marriage (Bayer, 1969; Modell, 1980; Thornton and Freedman, 1982). The older an individual's preferred marriage age, the later he or she tends to marry. Although we recognize the importance of the children's attitudes toward marital timing, we shift the emphasis to parental preferences in keeping with our focus on intergencrational effects. While the direction of the influence of parents' ideal ages for their children to marry has not been established by previous research, we expect that the older a parent's ideal age for their children to marry, the later those children will marry. This is the equivalent of saying that the influence of parents' ideal age on the probability a child marries during any one period is negative, postponing marriage to a later period.

A fifth causal mechanism begins from the position that parents have preferences about when their children should marry and use their resources to prevent marriages from occurring too early and facilitate marriage at more acceptable ages. As described above, parents' ideal ages for their children to marry are expected to have a negative effect on the probability a child marries in any given period, so that high parental ideal ages are likely to be correlated with later actual marriage ages. The more 
resources parents have the better able they will be to manipulate the timing of their children's marriages toward the parent's goals. Resources can be used both to provide alternatives to marriage before children reach the parents' ideal age and to facilitate the marital process once children reach parents' ideal age, thereby encouraging marriage (Waite and Spitze, 1981). After children have passed their parents' ideal age for them to marry, the parents' motivation for their children to marry should only increase, so that they use their resources to encourage marriage more and more. Since parents' ideal age is expected to have a negative influence on the probability of marrying in a given period and resources are expected to enhance parents' ability to manipulate children toward parents' goals, the interaction between parents' ideal age and parents' resources is expected to have a negative effect on the probability of marrying, delaying marriage, and adding to the negative effect of parents' ideal age alone. We test this hypothesis by using parents' ideal ages for their children to marry as stated by the parents themselves and evaluate the effect of interactions between this measure of preferences and parents' financial resources on children's marrying propensities.

Previous research about this causal mechanism has lacked direct information about parental preferences and has had to utilize children's ages as indirect measures of parents' preferences for their children to marry during any given period in the life course (Waite and Spitze, 1981). This indirect approach assumes that the desirability of an age for first marriage varies so that some ages are considered too early or too late while other ages are considered preferable (Modell, 1980). As children age, parents' desire for their children to marry at each particular age will increase monotonically. The closer to the desirable age individuals get, the more acceptable marriage becomes. As individuals mature past the most desirable age to marry, remaining single will become continuously less desirable. The result is that parents use their financial resources to encourage marriage more as children mature across the life course. We test this formulation of the parents' preferences-resources interaction by estimating the effects of the interaction of age and financial resources on the propensity to marry.

The ability of parents to influence the timing of their children's marriages at different points in the life course should also be considered. Educational attainment, employment, and independence have been linked to the timing of marriage by several investigators (Preston and Richards, 1975; Elder and Rockwell, 1976; Marini, 1978; Cherlin, 1980; Hirschman, 1985; Rodgers and Thornton, 1985), and the incidence of these factors increases as children age. These factors, along with the natural maturation of children with age, also could affect the ability of parents to influence the timing of their children's marriages. Waite, Goldscheider, and Witsberger (1986) found that residence away from parents prior to marriage is associated 
with changes in family attitudes and expectations among young adults. Currently, as individuals enter adulthood, most expect to experience living away from their parents before marriage (Goldscheider and Goldscheider, 1987). As individuals age, mature, become educated, become employed, and likely spend less time residing with their parents, parents will have decreasing opportunities and a declining ability to influence their children.

As stated earlier, the impact of the parents' ideal age at marriage on the age-specific probabilities of their children marrying will probably be negative at all ages. However, as children age and the influence of the parents declines, this effect will probably dissipate. That is, at young ages the direct effect of parents' ideal age for their children to marry may be quite strong, but as children progress through the life course the effect is expected to weaken. We test this hypothesis by estimating the effects of an interaction between parents' ideal ages for their children to marry and the children's own ages on the age-specific probabilities of transitions to marriage.

It is the aim of this paper to establish the overall effects of parental resources and marital timing preferences on the actual timing of the transition to first marriage. Toward this end, we test the effects of parents' incomes, assets, educations, and preferences on the timing of marriage. As discussed above, our theoretical reasoning suggests several mechanisms linking parental resources to the timing of marriage. While it would be desirable to document the exact mechanisms through which the parental family influences children's marriages, such analyses were beyond the scope of this paper. Analyses designed to demonstrate these mechanisms would require measures of the children's educational and work careers and their aspirations, all measured independently of the decision to marry, and each with timing specific enough to ensure the proper causal ordering. While inclusion of these dimensions of the children's lives would no doubt provide fruitful insights, we were unable to explore these mechanisms in this analysis. Nevertheless, we do provide accurate estimates of the overall effects of the parental family on children's marital timing. We also add tests of the influence of parents' resources on parents' ideal ages for children to marry and the effects of these preferences on the timing of marriage. Finally, we test the effects of parental resources as they interact with children's position in the life course and parental preferences. These tests represent an important empirical advancement in modeling the intergenerational effects on the timing of marriage.

\section{CONCEPTUAL ISSUES}

Explicit treatment of the idea that parents may use their resources to influence the timing of their children's marriages depending on their preferences requires consideration of the way parental resources are defined and used. On the one hand, there are monetary resources parents can 
use directly to influence their children's decision to marry by paying for things such as higher education, the formation of a new household, or the wedding ceremony itself. Such resources include the family's income and assets.

On the other hand, there are those resources that cannot be used to pay tuition, dorm fees, rent, or a minister. We consider the educational attainment of parents to be such a nonfinancial resource. While parents' educational attainment affects parents' ability to obtain financial resources which can be used directly to influence children, parents cannot directly transfer some portion of their educational attainment to their children as a method of influencing their children's decision to marry. Parents' educational attainment must influence their children's decision to marry via some other mechanism. Thus, we argue that one must differentiate between parental monetary and nonfinancial resources, such as parental educational attainment, when considering the influence of parents on the timing of marriage.

The arguments we have proposed are intended to clarify several complex features of the relationship between parental resources and the transition to first marriage. The timing of individuals' first marriage can be operationalized in empirical analyses as their age at first marriage. However, when those under examination have not all completed the transition to first marriage, this approach is flawed because those who have not yet married are censored out of analyses. Instead, the process is conceptualized here in terms of age-specific probabilities an individual will marry during a period given he or she was unmarried at the beginning of the period. The probability of marriage is considered at successive intervals across the life course. This conceptualization allows us to consider the influence of parental resources on the probability an individual marries as it changes with age (Waite and Spitz, 1981) without censoring out those who may not marry until older ages or those who never marry.

\section{METHODS}

The data used here come from a systematic probability sample of 1961 birth records chosen to represent white families who had just given birth to a first, second, or fourth child in the Detroit, Michigan, metropolitan area (Wayne, Oakland, and Macomb counties). The sample was stratified by parity to select approximately equal numbers of records from each birth order. An initial personal interview was conducted with the mothers in the winter of 1962, and telephone interviews were conducted in the fall of 1962 and in 1963,1966, 1977, 1980, and 1985. In 1980 (age 18.5) and 1985 (age 23.5) personal interviews were also conducted with the child born in 1961. Retrospective event history calendar information was obtained from the children in 1985.

The original response rate to the 1962 survey was $92 \%$, and high re- 
sponse rates have been maintained over the period 1962 to 1985 (Freedman, Thornton, and Camburn, 1980; Thornton, Freedman, and Camburn, 1982). In 1985 interviews were obtained with $82 \%$ of both mothers and children in families originally interviewed in $1962 .^{1}$

We constructed and analyzed 17 6-month person-periods representing the time between age 15 and age 23.5 for our respondents. Those who marry during a period were coded as 1 for that period and those who do not marry by the end of the period were coded zero for that period. Only those who had not married before a given period were analyzed in that period, and the respondent's age was used as a characteristic of each period. Thus, for each respondent, age changes by person-period, but other predictors were fixed across all person-periods. For the purpose of our analysis these 176 -month person-periods were pooled together and analyzed simultaneously. The result was that the unit of analysis was the person-period rather than the individual respondent. ${ }^{2}$

Of course, it is well known that marriage rates increase with age during the late teenage years and during the early twenties (Thornton, 1988; Rodgers and Thornton, 1985). Therefore we include the respondent's age as a time varying covariate in our models of the transition to first marriage. The first 6-month period (age 15-15.5) is coded 1, the second is coded 2 , the third is coded 3 , and so on.

We use as our measure of parental marital timing preferences the mothers' stated ideal age for their children to marry, which was ascertained when their children were age 18 (see Fig. 1). While this measure is an improvement over indirect methods of measuring parents preferences, it has the potential weakness of being measured relatively late in the life course. Measures of parents' preferences from earlier points in the children's life courses might be more independent of children's experiences on the marriage market. By age 18 parents' statements may be influenced by their children's dating behavior or early marital plans. Further, mothers are not likely to give an ideal marriage age younger than their children's age at the time they are asked, if their children are as yet unmarried. On

\footnotetext{
${ }^{1}$ Attrition from the panel is slightly selective toward the lower income groups. However, in a distribution of the sample population by income, bracketed into 20 income groups, the attrition makes less than a $1 \%$ difference in any of the income groups. Although those who leave the panel have a slight tendency to come from lower income groups, because the amount of attrition has been kept extremely low, it has had almost no effect on the composition of the sample.

${ }^{2}$ The pooling of person-periods results in a number of person-periods for analysis that is much higher than the original number of respondents. However, pooling person-periods does produce an accurate, unbiased representation of the discrete time hazard of marrying (Allison, 1982). This discrete time approach creates no special disadvantages relative to a continuous time approach (Allison, 1982). Furthermore, the increased number of cases used in analyses does not affect our measures of statistical significance (Peterson, 1986).
} 


\begin{tabular}{|c|c|c|c|c|}
\hline $\begin{array}{l}\text { VARIABLE } \\
\text { NAME }\end{array}$ & VARIABLE DESCRIPTION & VALUE RANGE & MEAN & $\begin{array}{c}\text { DATE } \\
\text { COLLECTED }\end{array}$ \\
\hline $\begin{array}{l}\text { PARENTAL } \\
\text { INCONE }\end{array}$ & $\begin{array}{l}\text { MEAN OF MOTHER'S } 1976 \text {, } \\
1979 \text {, AND } 1984 \text { FAIILY } \\
\text { INCOYE IN } 1984 \text { DOLLARS }\end{array}$ & $\begin{array}{c}\$ 4103 \\
\text { T0 } \\
\$ 141,839\end{array}$ & $\$ 46,715$ & $1977,1980,1985$ \\
\hline $\begin{array}{l}\text { PARENTAL } \\
\text { TOTAL ASSETS }\end{array}$ & $\begin{array}{l}\text { FAMILY'S TOTAL ASSETS } \\
\text { (LIQUID PLUS HOME EQUITY) }\end{array}$ & $\begin{array}{l}\$ 250 \text { TO } \\
\$ 120,000\end{array}$ & $\$ 37,958$ & 1977 \\
\hline $\begin{array}{l}\text { PARENTAL } \\
\text { EDUCATION }\end{array}$ & $\begin{array}{l}\text { SUM OF MOTHER'S AND } \\
\text { FATHER'S YEARS OF } \\
\text { EDUCATION }\end{array}$ & 6 TO 32 & 24.6 & 1962 \\
\hline $\begin{array}{l}\text { MOTHER 'S } \\
\text { IDEAL } \\
\text { AGE }\end{array}$ & $\begin{array}{l}\text { MOTHER'S STATEMENT OF } \\
\text { HER IDEAL AGE FOR THIS } \\
\text { CHILD TO MARRY (MINUS 17) }\end{array}$ & 1 TO 18 & 7.4 & 1980 \\
\hline CONTROLS & & & & \\
\hline $\begin{array}{l}\text { MOTHER'S } \\
\text { TOTAL } \\
\text { CHIIDREN }\end{array}$ & $\begin{array}{l}\text { TOTAL NUMBER OF } \\
\text { CHILDREN BORN TO } \\
\text { MOTHER }\end{array}$ & 1 TO 10 & 3.8 & 1977 \\
\hline $\begin{array}{l}\text { MOTHER'S } \\
\text { PREMARITAL } \\
\text { PREGNANCY }\end{array}$ & $\begin{array}{l}\text { ONE IF MOTHER WAS } \\
\text { PREGNANT AT } \\
\text { MARRIAGE }\end{array}$ & 0 To 1 & .18 & 1962 \\
\hline $\begin{array}{l}\text { MOTHER'S } \\
\text { AGE AT } \\
\text { MARRIAGE }\end{array}$ & $\begin{array}{l}\text { MOTHER'S AGE AT } \\
\text { FIRST MARRIAGE }\end{array}$ & 11 To 34 & 20.5 & 1962 \\
\hline $\begin{array}{l}\text { IF MOTHER } \\
\text { WIDOWED }\end{array}$ & $\begin{array}{l}\text { ONE IF MOTHER WAS } \\
\text { WIDOWED BY FATHER } \\
\text { BETWEEN } 1962 \text { AND } 1980\end{array}$ & 0 TO 1 & .04 & $1962-1980$ \\
\hline $\begin{array}{l}\text { IF MOTHER } \\
\text { DIVORCED AND } \\
\text { REKARRIED }\end{array}$ & $\begin{array}{l}\text { ONE IF MOTHER WAS } \\
\text { DIVORCED FRON FATHER } \\
\text { AND REMARRIED } 1962-1980\end{array}$ & 0 Tо 1 & .09 & $1962-1980$ \\
\hline $\begin{array}{l}\text { IF MOTHER } \\
\text { DIVORCED AND } \\
\text { NOT REMARRIED }\end{array}$ & $\begin{array}{l}\text { ONE IF MOTHER WAS } \\
\text { DIVORCED FROM FATHER } \\
\text { AND NOT REYARRIED 1962-1980 }\end{array}$ & 0 To 1 & .11 & $1962-1980$ \\
\hline
\end{tabular}

Fig. 1. Description of variables used to analyze transition to marriage. All data were collected from mothers, except the mother's premarital pregnancy, which was ascertained by a record check.

the other hand, it is likely that parents revise their preferences as their children pass through the life course. Therefore, it would have been useful to have had updated measures of parental preferences as children matured across the years from 18 to 23 . Certainly the issue is complex, but we feel our measure, taken directly from parents themselves, represents an important step in the right direction. ${ }^{3}$

${ }^{3}$ Note that the mothers' mean ideal ages for their sons to marry is somewhat higher than their ideal ages for their daughters to marry. The mean of mothers' ideal ages for sons to marry was 25.1 years (with a standard deviation of 2.1 years) and the mean of mothers' 
Because the mothers' statements of their ideal ages for their children to marry were gathered when the children were age 18 , the time periods examined for analyses of models including ideal age began when the children turned age 19 . This approach minimized the possibility that parents' stated ideal age for their children to marry reflected parents' knowledge that their children might have been planning a marriage in the immediate future. These analyses, therefore, included only the 96 -month person-periods from age 19 to age 23.5 .

Some measures of parental characteristics were combined to provide composite variables and avoid collinearity among subsets of measures (Alwin and Thornton, 1984). Parents' nonfinancial resources were measured by the sum of mother's and father's educational attainment as of 1962 (see Fig. 1). Parents' financial resources were measured by the families' permanent incomes over the period of the children's lives being considered here. That is, parents' financial resources were measured by the mean (in 1984 dollars) of the family income in 1976, 1979, and 1984 or, in terms of the children being studied, at ages 14-15, 17-18, and 2223. Alternate models with financial resources measured by the families' 1976 total assets were also tested. Researchers often measure parental resources by asking children to report characteristics of their parents. Our data represent an advancement over this approach by measuring both financial and nonfinancial resources using reports by the mother of her own situation.

Only the report of the timing of the children's marriages was taken from the children. This report was obtained using a life history calendar. The life history calendar is a technique for collecting retrospective event history data and also provides the precise timing of the event in question (Freedman et al., 1988). Data on the children's transition to their first marriage were available up to the 6-month period ending when they became age twenty-three and a half. While we are unable to analyze the marriage process beyond age 23.5 , our models do provide accurate estimates of the influence of parental resources on the transition to marriage before age 23.5 , and those estimates provide important insights into hypotheses linking parental resources to marriage timing.

Several scholars studying the marriage process have noted gender differences (Goldscheider and Goldscheider, 1987; Kobrin and Waite, 1984; Goldscheider and Waite, 1986; Marini, 1978). Because of this evidence, the influence of parental resources on the timing of children's marriage was modeled separately for males and females.

There is also good reason to believe that several dimensions of the

idcal ages for daughters to marry was 23.8 years (with a standard deviation of 2.2 years). Since our study last interviewed these young people at age 23.5 the actual marital experience in these analyses occurs before reaching mothers' mean ideal age for either sex. 
mother's background considered causally prior to the processes examined here should be taken into account while modeling the timing of an individual's marriage. These factors include the mother's age at marriage, whether or not she had a premarital pregnancy, and her marital experience (Kobrin and Waite, 1984; McLanahan and Bumpass, 1988; Thornton, 1991). Because a good deal has already been written about the effects of these factors on marriage timing, we do not discuss their effects in the text, but we do include measures of these factors as controls in our models of marital timing. In the analyses the mothers' marital experience was modeled using a series of dummy variables. The first was coded 1 if the children's mothers were widowed by their fathers between 1962 and 1980, the second was coded 1 if mothers were divorced and remarried during that period, and the third was coded 1 if mothers divorced but had not remarried by 1980 . Thus, mothers who remained married to the child's father over the entire period were the reference group for these comparisons. In addition, the number of siblings an individual has was taken into account since the parental resources available for children were probably split among those siblings.

Pooling person-periods produces a discrete time hazard analysis of first marriage (Allison, 1982, 1984). The discrete time approach allows us to include time varying covariates and interactions with time varying covariates to test the interactive hypotheses described above. The dependent variable for this discrete time analysis is dichotomous, whether or not an individual married during a period given that he or she had not married before, so logistic regression is an appropriate estimation technique (Allison, 1984; Kmenta, 1986; Maddala, 1983). The logistic regression equations we estimated were $\ln (p / 1-p)=a+\Sigma\left(B_{\mathrm{k}} * X_{\mathrm{k}}\right)$, where $p$ is the 6-month probability of a marriage occurring, $p / 1-p$ is the 6-month odds of marriage, $X_{\mathbf{k}}$ represents the explanatory variables included in the model, $B_{\mathrm{k}}$ represents the effects parameters associated with those variables, and $a$ is a constant term. The tables present our estimates of the logistic effects parameters $\left(B_{\mathrm{k}}\right)$, but we also discuss the antilogs of some of the parameter estimates in order to facilitate interpretation of results. The antilogs of the coefficients can be interpreted as the amount that the odds are multiplied for each unit change in the explanatory variable (Morgan and Teachman, 1988).

\section{RESULTS}

\section{Predicting Preferred Age at Marriage}

We begin by considering the hypotheses predicting that parental resources increase mothers' preferred age at marriage for their children. Note that our models predicting mothers' preferences were estimated using ordinary least-squares (OLS) techniques since the distribution of this vari- 
TABLE 1

Multivariate OLS Regression Estimations of Models of Mother's Ideal Age for Child to Marry ( $t$-ratios in parentheses)

\begin{tabular}{|c|c|c|c|c|}
\hline \multirow[b]{2}{*}{ MODEL } & \multicolumn{2}{|c|}{ FFyALES } & \multicolumn{2}{|c|}{ MALES } \\
\hline & I & II & I & II \\
\hline $\begin{array}{l}\text { INCOME } \\
\text { (THOUSANDS) }\end{array}$ & $\begin{array}{l}.002 \\
(.28)\end{array}$ & & $\frac{.012 \star}{(2.14)}$ & \\
\hline $\begin{array}{l}\text { TOTAL ASSETS } \\
\text { (THOUSANDS) }\end{array}$ & & $\begin{array}{l}.003 \\
(.54)\end{array}$ & & $\begin{array}{r}.006 \\
(1.20)\end{array}$ \\
\hline $\begin{array}{l}\text { PARENTAL } \\
\text { EDUCATION }\end{array}$ & $(1.75)$ & $(2.080)$ & $(1.69)$ & $(2.53)$ \\
\hline $\begin{array}{l}\text { MOTHER'S TOTAL } \\
\text { CHILDREN }\end{array}$ & $\begin{array}{l}.09 \\
(.96)\end{array}$ & $\begin{array}{c}.09 \\
(1.17)\end{array}$ & $\begin{array}{l}-.05 \\
(-.73)\end{array}$ & $\begin{array}{c}-.05 \\
(-.76)\end{array}$ \\
\hline $\begin{array}{l}\text { MOTHER'S } \\
\text { PREMARITAL } \\
\text { PREGNANCY }\end{array}$ & $\begin{array}{l}.22 \\
(.77)\end{array}$ & $\begin{array}{l}.26 \\
(.98)\end{array}$ & $\begin{array}{l}.11 \\
(.35)\end{array}$ & $\begin{array}{l}.13 \\
(.44)\end{array}$ \\
\hline $\begin{array}{l}\text { MOTHER'S AGE } \\
\text { AT MARRIAGE }\end{array}$ & $\begin{array}{c}.05 \\
(1.37)\end{array}$ & $\begin{array}{c}.05 \\
(1.45)\end{array}$ & $\begin{array}{r}-.004 \\
(-.11)\end{array}$ & $\begin{array}{l}-.02 \\
(-.50)\end{array}$ \\
\hline $\begin{array}{l}\text { IF MOTHER } \\
\text { WIDOWED }\end{array}$ & $\begin{array}{l}-.31 \\
(-.54)\end{array}$ & $\begin{array}{c}-.09 \\
(-.18)\end{array}$ & $\begin{array}{c}.72 \\
(1.31)\end{array}$ & $\begin{array}{l}.35 \\
(.66)\end{array}$ \\
\hline $\begin{array}{l}\text { IF MOTHER } \\
\text { DIVORCED AND } \\
\text { REMARRIED }\end{array}$ & $\begin{array}{l}1.04 \star \star \\
(2.45)\end{array}$ & $\begin{array}{l}.97 * \star \\
(2.42)\end{array}$ & $\begin{array}{l}.17 \\
(.41)\end{array}$ & $\begin{array}{l}.22 \\
(.54)\end{array}$ \\
\hline $\begin{array}{l}\text { IF MOTHER } \\
\text { DIVORCED AND } \\
\text { NOT REMARRIED }\end{array}$ & $\begin{array}{c}.67 \star \star \\
(1.67)\end{array}$ & $(2.33)$ & $\begin{array}{l}1.78 \star \star \star \star \\
(4.78)\end{array}$ & $\begin{array}{l}1.46 * \star \star \star \\
(4.26)\end{array}$ \\
\hline $\begin{array}{l}\text { R-SQUARE } \\
\text { ADJUSTED }\end{array}$ & .022 & .035 & .067 & .052 \\
\hline $\mathbf{F}$ & $2.0 *$ & $2.7 * \star$ & 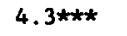 & $3.7 * \star \star$ \\
\hline $\begin{array}{l}\text { NUMBER OF } \\
\text { RESPONDENTS }\end{array}$ & 356 & 378 & 368 & 394 \\
\hline * P $<.05$ & $\star * \quad P<.01$ & $* \star * \quad P<.001$ & ONE-I & \\
\hline
\end{tabular}

able approximates an interval measure. Parents' educational attainment had a clear, consistent, significant positive influence on mothers' ideal ages for both their sons and dauthers to marry (see Table 1). That is, the more education parents had, the higher their ideal age for their children to marry.

For sons, parental income had a positive, significant effect on mothers' ideal age for them to marry. The total assets measure of financial resources also had a positive effect, but the coefficient was not significant. For 
daughters, however, parents' financial resources appear to have little effect on mothers' ideal age for their daughters to marry. Neither the income, nor the total asset coefficients were significantly different from zero.

Parents' education may cause higher preferred ages for children to marry because parents' education produces higher aspirations for the amount of education their children attain before marrying. If so, this effect appears to operate similarly for both daughters and sons. Perhaps financial resources also produce higher preferred ages of marriage for children because parents with more financial resources expect their children to attain greater financial resources before marrying. If so, the lack of a significant effect among daughters may indicate that parents expect their sons to attain higher levels of financial resources before marrying than their daughters.

Among the controls only the mothers's marital history variables had significant effects. For daughters, all mothers who divorced had significantly higher ideal ages for their daughters to marry, but among sons only mothers who divorced and did not remarry had significantly higher ideal ages for their sons to remarry. Overall, the models each explained less than $10 \%$ of the variance in mothers' ideal age for their children to marry.

\section{Marriage Probabilities-Additive Effects}

The data were also consistent with hypotheses predicting a negative influence of both financial and nonfinancial resources on the probability of marrying. Table 2 presents the coefficients from logistic regression estimates of discrete time hazard models of first marriage. All of the estimated coefficients for all of the parental resource variables were in the predicted direction. Looking first at financial resources, we see that parents' total assets had a statistically significant, negative influence on the probability of marrying among both sons and daughters. While income has the expected coefficient, its effect on the timing of marriage for both sons and daughters was not statistically significant. The observed negative effects of the financial resource variables on these marital transitions indicate a delaying effect on the timing of marriage since any factor which reduces the probability of marrying in one period postpones marriage to a later period or leads to never marrying. Thus, parents' financial resources, especially as measured by total assets, tend to delay their children's transition to marriage. This result is consistent with both the hypothesis that children may be less motivated to leave homes with many resources via marriage and the hypothesis that children delay marriage in order to achieve a higher level of financial resources before they marry. Since we have just seen that financial resources also increase mothers' desired age at marriage for their children, the observed relationship be- 
TABLE 2

Logistic Regression Estimates of Additive Effects of Resources on the Probability of Marrying ( $t$-ratios in parentheses)

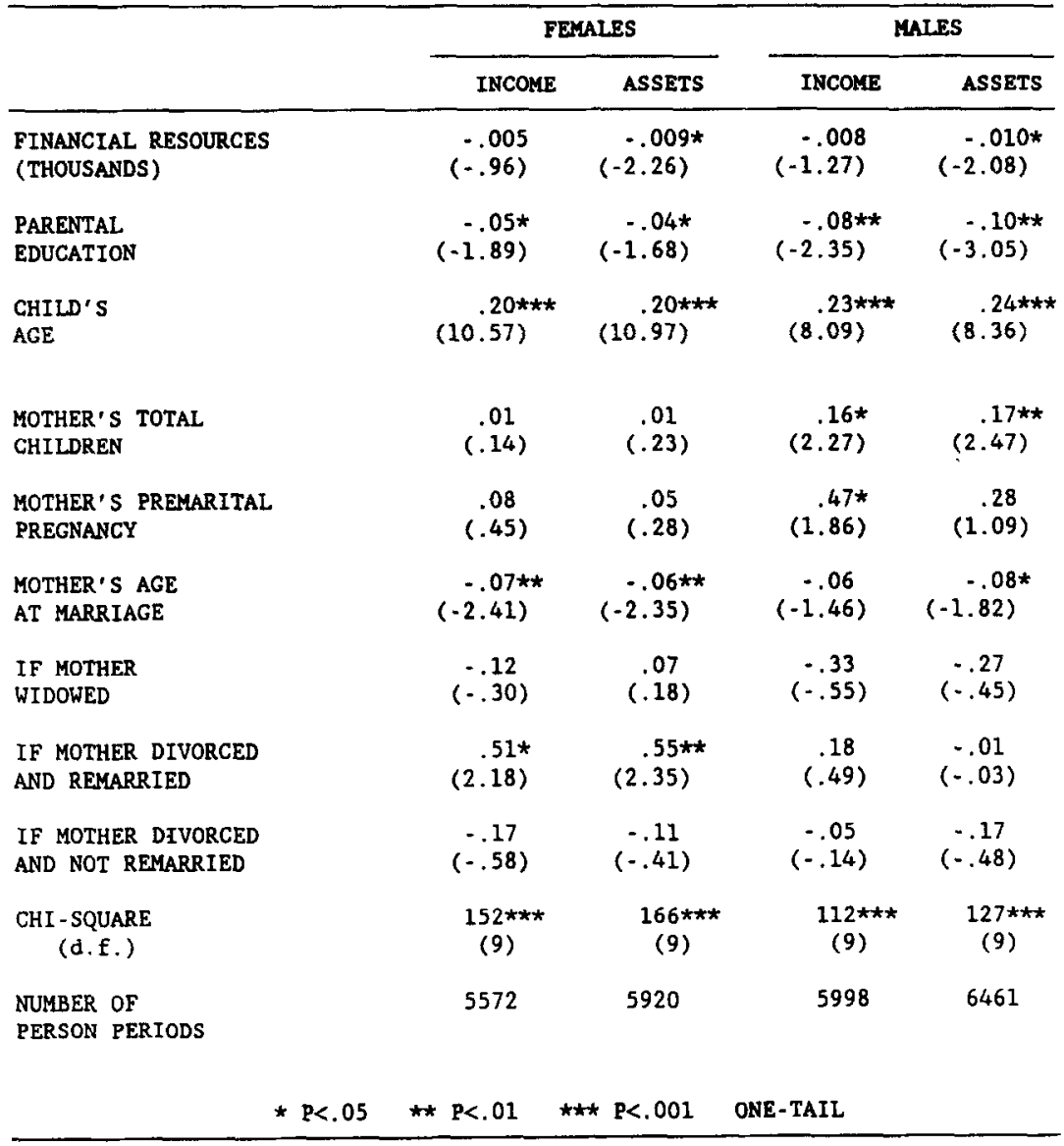

tween resources and marital timing may also reflect the parental preferences mechanism.

Shifting to nonfinancial resources, parents' educational attainment also had a significant, negative influence on the probability of marrying among both sons and daughters. Although the coefficient for this effect was larger among sons than among daughters, it represents a delaying effect of parental education on the timing of marriage for children of both sexes. The logit coefficient of -.05 for daughters translates to an odds coefficient of .95. This implies that each additional year of parents' schooling reduces daughters' rates of marriage by 5\%. A young woman with two parents who graduated from a 4-year college would marry at only two-thirds the rate of a young woman with parents who only graduated from high school. 
For sons the logit coefficient of -.10 translates to an odds coefficient of .90. This implies that a young man with two parents who graduated from college would marry at less than half the rate of a young man with two parents who only graduated from high school.

These findings are consistent with the hypothesis that parents' education increases the educational aspirations and attainment of children, delaying children's transition to marriage. The weaker effect among females may be because parents' education has less effect on daughters' educational aspirations, enrollment, and attainment. It may also be because daughters' educational aspirations, enrollment, and attainment have less effect on their decision to marry than do sons' educational aspirations, enrollment, and attainment. In fact, evidence presented elsewhere is consistent with the latter hypothesis (Thornton, Axinn, and Teachman, 1992). Also note that some of the observed relationship between parental education and children's marital timing probably operates via the mothers' preferences, as indicated in Table 1.

The age of the respondent at the period of risk had a significant positive influence on the age-specific marriage probabilities of both daughters and sons. This result is consistent with our expectation that this portion of the life course is a period when the rates of marrying increase rapidly with age.

\section{Age-Resource Interactions}

To test the hypotheses that the influence of parents' resources depends on their children's positions in the life course, we added the appropriate interaction terms to our additive models. First we added an age-income and an age-total assets interaction term. This procedure uses age as an indirect measure of parents' aspirations for the timing of their children's marriages, as noted in our earlier discussion. Previous analyses have used the child's age as a proxy for parental preferences, but not in a discretetime hazard format which provides a test of statistical significance (Waite and Spitze, 1981). Our results are displayed in Table 3.

Neither the age-income nor the age-assets interactions had a significant influence on the timing of the transition to marriage for either sons or daughters. This result is not consistent with the hypothesis focusing on parents' preferences for using their resources to manipulate the timing of their children's marriages. Of course, using age as an indirect approach to measuring parents' preferences for the timing of their children's marriages may be insufficient. Below we explore this hypothesis again using mothers' ideal ages for their children to marry as a more direct approach to measuring parents' preferences.

To test the hypothesis that the delaying effect of parental education depends on the children's position in the life course we added an ageparental education interaction term to our additive models of marriage 
TABLE 3

Logistic Regression Estimates of Effects of Age-Financial Resource Interactions on the Probability of Marrying ( $t$-ratios in parentheses)

\begin{tabular}{|c|c|c|c|c|}
\hline & \multicolumn{2}{|c|}{ FEMALES } & \multicolumn{2}{|c|}{ MALES } \\
\hline & INCOME & ASSETS & INCONE & ASSETS \\
\hline $\begin{array}{l}\text { FINANCIAI RESOURCES } \\
\text { (THOUSANDS) }\end{array}$ & $\begin{array}{l}-.012 \\
(-.90)\end{array}$ & $\begin{array}{c}-.01 \\
(-1.17)\end{array}$ & $\begin{array}{l}-.007 \\
(-.37)\end{array}$ & $\begin{array}{c}-.03 \\
(-1.60)\end{array}$ \\
\hline $\begin{array}{l}\text { PARENTAL } \\
\text { EDUCATION }\end{array}$ & $\begin{array}{r}-.05 \star \\
(-1.90)\end{array}$ & $\begin{array}{r}-.04 \star \\
(-1.69)\end{array}$ & $\begin{array}{r}-.08 \pi \\
(-2.35)\end{array}$ & $\begin{array}{l}-.10 * * \\
(-3.02)\end{array}$ \\
\hline $\begin{array}{l}\text { CHILD'S } \\
\text { AGE }\end{array}$ & $(3.83)$ & $\begin{array}{l}.19 * \star \star \\
(5.95)\end{array}$ & $(3.44)$ & $\begin{array}{l}.20 * * \star \\
(4.05)\end{array}$ \\
\hline $\begin{array}{l}\text { AGE } \star \text { FINANCIAL RESOURCES } \\
\text { INTERACTION (THOUSANDS) }\end{array}$ & $\begin{array}{l}.001 \\
(.58)\end{array}$ & $\begin{array}{l}.0003 \\
(.40)\end{array}$ & $\begin{array}{l}-.0001 \\
(-.04)\end{array}$ & $\begin{array}{r}.002 \\
(1.09)\end{array}$ \\
\hline $\begin{array}{l}\text { MOTHER'S TOTAL } \\
\text { CHILDREN }\end{array}$ & $\begin{array}{l}.008 \\
(.13)\end{array}$ & $\begin{array}{l}.013 \\
(.22)\end{array}$ & $\begin{array}{l}.16 * \\
(2.27)\end{array}$ & $\frac{.17 * *}{(2.45)}$ \\
\hline $\begin{array}{l}\text { MOTHER'S PREMARITAL } \\
\text { PREGNANCY }\end{array}$ & $\begin{array}{l}.08 \\
(.46)\end{array}$ & $\begin{array}{l}.05 \\
(.29)\end{array}$ & $(1.86)$ & $(1.08)$ \\
\hline $\begin{array}{l}\text { MOTHER'S AGE } \\
\text { AT MARRIAGE }\end{array}$ & $\begin{array}{l}-.07 * \star \\
(-2.41)\end{array}$ & $\begin{array}{l}-.06 * \star \\
(-2.34)\end{array}$ & $\begin{array}{c}-.06 \\
(-1.46)\end{array}$ & $\begin{array}{r}-.08 * \\
(-1.80)\end{array}$ \\
\hline $\begin{array}{l}\text { IF MOTHER } \\
\text { WIDOWED }\end{array}$ & $\begin{array}{c}-.12 \\
(-.31)\end{array}$ & $\begin{array}{l}.07 \\
(.18)\end{array}$ & $\begin{array}{l}-.33 \\
(-.55)\end{array}$ & $\begin{array}{l}-.26 \\
(-.44)\end{array}$ \\
\hline $\begin{array}{l}\text { IF MOTHER DIVORCED } \\
\text { AND REMARRIED }\end{array}$ & $\begin{array}{r}.51 \star \\
(2.17)\end{array}$ & $\begin{array}{r}.55 \star \\
(2.33)\end{array}$ & $\begin{array}{l}.18 \\
(.49)\end{array}$ & $\begin{array}{l}-.03 \\
(-.08)\end{array}$ \\
\hline $\begin{array}{l}\text { IF MOTHER DIVORCED } \\
\text { AND NOT REMARRIED }\end{array}$ & $\begin{array}{l}-.17 \\
(-.59)\end{array}$ & $\begin{array}{l}-.11 \\
(-.41)\end{array}$ & $\begin{array}{c}-.05 \\
(-.14)\end{array}$ & $\begin{array}{l}-.17 \\
(-.51)\end{array}$ \\
\hline $\begin{array}{l}\text { CHI - SQUARE } \\
\text { (d.f.) }\end{array}$ & $\begin{array}{l}152 * * * \\
(10)\end{array}$ & $\begin{array}{l}166 * * * \\
(10)\end{array}$ & $\begin{array}{l}112 * * * \\
(10)\end{array}$ & $\begin{array}{l}128 * * * \\
(10)\end{array}$ \\
\hline $\begin{array}{l}\text { NUMBER OF } \\
\text { PERSON PERIODS }\end{array}$ & 5572 & 5920 & 5998 & 6461 \\
\hline$\star P<.05$ & ** $\mathrm{P}<.01$ & $P<.001$ & ONE-TAIL & \\
\hline
\end{tabular}

timing. This interaction term worked as the hypothesis predicted (see Table 4). It had a positive effect on the probability of marrying among both males and females, though it was only significant among females. That is, parental education has a negative effect on the probability of marrying, thereby postponing marriage, but as children age this negative effect becomes weaker (as we add the positive effect from the age-parental education interaction). This result is consistent with our hypothesis that parental education increases children's educational enrollments, thus delaying marriage, but that at older ages enrollment declines, and this effect of education weakens. The effect of this interaction might have failed the statistical significance test among sons because the impact of educational 
TABLE 4

Logistic Regression Estimates of Effects of Age-Education Interactions on the Probability of Marrying ( $t$-ratios in parentheses)

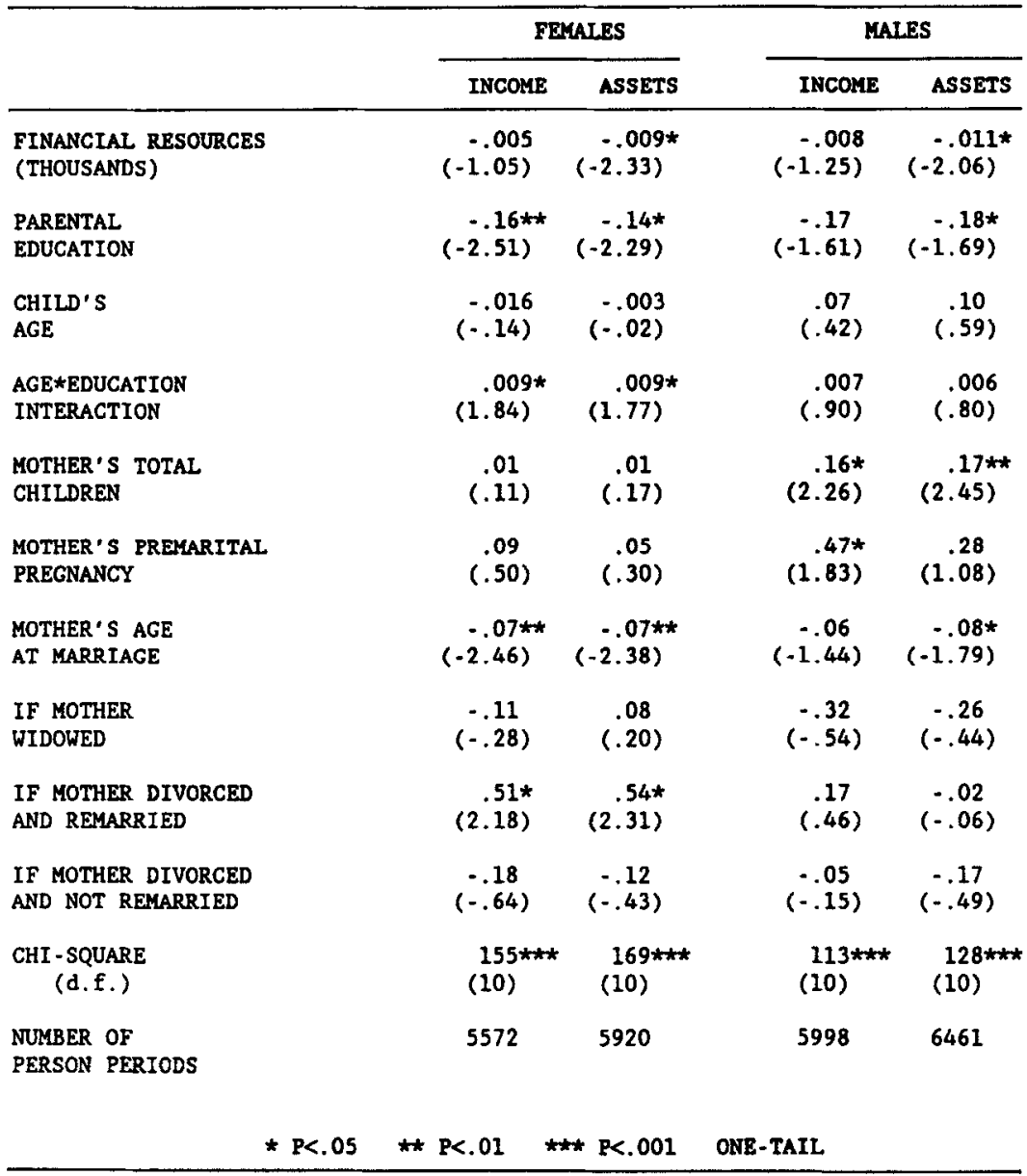

enrollment may persist longer across the life course for men than for women. Since our study only follows young people through age 23.5 , it is possible that some of the young men with highly educated parents are still enrolled in school.

\section{Ideal Age and Ideal Age Interactions}

We now shift the analysis to the effects of parents' ideal ages for their children's marriages and the way parental preferences interact with parental resources. Note that the differences among coefficients in models containing mother's ideal age (Table 5) and previous models reflect both 
TABLE 5

Logistic Regression Estimates of Additive Effects of Mother's Ideal Age on the Probability of Marrying ( $t$-ratios in parentheses)

\begin{tabular}{|c|c|c|c|c|}
\hline & \multicolumn{2}{|c|}{ FEMALES } & \multicolumn{2}{|c|}{ MALES } \\
\hline & INCOME & ASSETS & INCOKE & ASSETS \\
\hline $\begin{array}{l}\text { FINANCIAL RESOURCES } \\
\text { (THOUSANDS) }\end{array}$ & $\begin{array}{r}-.005 \\
(-.89)\end{array}$ & $\begin{array}{r}-.01 * \\
(-2.22)\end{array}$ & $\begin{array}{r}-.006 \\
(-.90)\end{array}$ & $\begin{array}{c}-.01 * \\
(-1.91)\end{array}$ \\
\hline $\begin{array}{l}\text { PARENTAL } \\
\text { EDUCATION }\end{array}$ & $\begin{array}{l}-.02 \\
(-.73)\end{array}$ & $\begin{array}{r}-.007 \\
(-.26)\end{array}$ & $(-2.07 *$ & $\begin{array}{l}-.10 \star \star \\
(-2.80)\end{array}$ \\
\hline $\begin{array}{l}\text { CHILD'S } \\
\text { AGE }\end{array}$ & $\begin{array}{l}.10 * \star \star \\
(3.11)\end{array}$ & $\begin{array}{l}.10 * \star * \\
(3.25)\end{array}$ & $(2.57)$ & $\begin{array}{l}.13 * * \\
(2.97)\end{array}$ \\
\hline $\begin{array}{l}\text { MOTHER'S } \\
\text { IDEAI AGE }\end{array}$ & $\begin{array}{l}-.15 * \star \star \\
(-3.46)\end{array}$ & $\begin{array}{l}-.15 * * * \\
(-3.54)\end{array}$ & $\begin{array}{l}-.25 * \star \star \\
(-4.21)\end{array}$ & $\begin{array}{l}-.22 \star \star \star \\
(-3.86)\end{array}$ \\
\hline $\begin{array}{l}\text { MOTHER'S TOTAL } \\
\text { CHILDREN }\end{array}$ & $\begin{array}{l}-.03 \\
(-.52)\end{array}$ & $\begin{array}{c}-.03 \\
(-.41)\end{array}$ & $(1.84)$ & $\begin{array}{l}.16 * \\
(2.20)\end{array}$ \\
\hline $\begin{array}{l}\text { MOTHER'S PREMARITAL } \\
\text { PREGNANCY }\end{array}$ & $\begin{array}{l}.16 \\
(.77)\end{array}$ & $\begin{array}{l}.11 \\
(.52)\end{array}$ & $(1.79)$ & $\begin{array}{l}.26 \\
(.98)\end{array}$ \\
\hline $\begin{array}{l}\text { MOTHER'S AGE } \\
\text { AT MARRIAGE }\end{array}$ & $(-2.064)$ & $\begin{array}{r}-.06 * \\
(-1.95)\end{array}$ & $\begin{array}{c}-.06 \\
(-1.49)\end{array}$ & $\begin{array}{r}-.08 * \\
(-1.83)\end{array}$ \\
\hline $\begin{array}{l}\text { IF MOTHER } \\
\text { WIDOWED }\end{array}$ & $\begin{array}{c}-.13 \\
(-.30)\end{array}$ & $\begin{array}{l}.10 \\
(.24)\end{array}$ & $\begin{array}{r}-.007 \\
(-.01)\end{array}$ & $\begin{array}{r}-.007 \\
(-.01)\end{array}$ \\
\hline $\begin{array}{l}\text { IF MOTHER DIVORCED } \\
\text { AND REMARRIED }\end{array}$ & $\begin{array}{l}.45 * \\
(1.67)\end{array}$ & $\begin{array}{l}. .45 * \\
(1.64)\end{array}$ & $\begin{array}{l}.17 \\
(.43)\end{array}$ & $\begin{array}{l}.003 \\
(.01)\end{array}$ \\
\hline $\begin{array}{l}\text { IF MOTHER DIVORCED } \\
\text { AND NOT REMARRIED }\end{array}$ & $\begin{array}{l}-.22 \\
(-.70)\end{array}$ & $\begin{array}{l}-.09 \\
(-.29)\end{array}$ & $(.26)$ & $\begin{array}{l}.13 \\
(.37)\end{array}$ \\
\hline $\begin{array}{l}\text { CHI - SQUARE } \\
\text { (d.f.) }\end{array}$ & $\begin{array}{l}37 \star * \star \\
(10)\end{array}$ & $\begin{array}{l}40 * \star \star \\
(10)\end{array}$ & $\begin{array}{l}53 * * * \\
(10)\end{array}$ & $\begin{array}{l}61 * * * \\
(10)\end{array}$ \\
\hline $\begin{array}{l}\text { NUMBER OF } \\
\text { PERSON PERIODS }\end{array}$ & 2553 & 2724 & 3008 & 3246 \\
\hline$\star P<.0$ & $* * P<.01$ & * $P<.001$ & ONE.TAIL & \\
\hline
\end{tabular}

including this variable and a reduction in the range of person-periods examined. Equations which contained the mother's ideal age variable included only the 6-month person-periods from age 19 to age 23.5 , not the full range from age 15 to 23.5 . Thus, some of the differences in coefficients across models resulted from restricting the analysis to later person-periods and not just from including the mother's ideal age variable. For example, the coefficient on age in the models including mother's ideal age was only one-half of that when mothers' ideal age is not included, but this result was likely due to restricting the number of person-periods analyzed rather than adding the ideal age at marriage variable. 
The influence of mothers' ideal ages for their children to marry was striking. It had a significant negative influence on marriage transitions for both dauthers and sons (see Table 5). The logit coefficient of -.15 for women translates to an odds coefficient of .86 , indicating that each year of preferred age at marriage reduces the marriage odds by $14 \%(1.0-$ .86). This odds coefficient implies that women with mothers who believe they should marry at age 27 marry at less than half the rate of women with mothers who believe they should marry at age 22 . The logit coefficient of -.25 for men translates to an odds coefficient of .77. This implies that young men with mothers who believe they should marry at 27 marry at less than $30 \%$ the rates of young men with mothers who believe they should marry at age 22 . Thus the magnitude of the effect of mothers' preferences is quite large for both sexes.

These findings are consistent with the hypothesis that parents' ideal age for their children to marry affects the timing of their child's marriage. The higher a mother's ideal age for her child to marry, the less likely her child is to marry in any particular period and the more likely her child is to delay marriage until a later period. The result is that young people with mothers who prefer they marry late do marry at significantly lower rates than other young people.

Using this direct approach to measuring parental preferences, we found new support for the hypothesis predicting that parents' use their resources to manipulate the timing of children's marriages toward parents' preferences. We examined this hypothesis using both a mother's ideal ageincome interaction term and a mother's ideal age-assets interaction term. In contrast to the analyses of interactions with age, the mother's ideal age-income interaction among daughters and mother's ideal age-assets interaction among sons were both in the predicted direction and significant (see Table 6A). The significant, negative effects of the mother's ideal age-financial resources interactions are consistent with the interpretation that mothers' ideal age has a delaying effect on the timing of marriage, and the more income parents have the better able they are to influence the timing of their children's marriages toward their goal. It is not clear why the appropriate measure of financial resources for this interaction appears to be income among daughters and assets among sons. Nonetheless, these results are consistent with the conclusion that the hypothesis focusing on this effect of parents' on their children's marital timing has some merit.

Finally, in order to test the hypothesis that the direct effect of parents' ideal age for their children to marry weakens as the children age, we introduced an age-mother's ideal age interaction term into our additive models. Again, the results are striking (see Table 6B). As expected, the age-mother's ideal age interaction was positive among both sons and daughters. The interaction is statistically significant among daughters in 
TABLE 6

Logistic Regression Estimates of Ideal Age Interaction Terms ( $t$-ratios in parentheses)

\begin{tabular}{|c|c|c|c|c|}
\hline & \multicolumn{2}{|c|}{ FEMALES } & \multicolumn{2}{|c|}{ MALES } \\
\hline & INCOME & ASSETS & INCO:LE & ASSETS \\
\hline $\begin{array}{l}\text { A. Effects of Ideal Age } \\
\text { Probability of Marry }\end{array}$ & $\begin{array}{l}\text { Financial R } \\
\text { ng }^{1}\end{array}$ & source Inter & ctions on $t$ & the \\
\hline $\begin{array}{l}\text { FINANCIAL RESOURCES } \\
\text { (THOUSANDS) }\end{array}$ & $\begin{array}{r}.014 \\
(1.18)\end{array}$ & $\begin{array}{l}-.004 \\
(-.26)\end{array}$ & $\begin{array}{l}-.003 \\
(-.13)\end{array}$ & $(1.30)$ \\
\hline $\begin{array}{l}\text { CHILD'S } \\
\text { AGE }\end{array}$ & $(3.11 * * *$ & $\begin{array}{l}.10 * \star * \\
(3.25)\end{array}$ & $(2.57)$ & $\begin{array}{l}.13 * * \\
(3.01)\end{array}$ \\
\hline $\begin{array}{l}\text { MOTHER'S } \\
\text { IDEAL AGE }\end{array}$ & $\begin{array}{l}-.02 \\
(-.31)\end{array}$ & $\begin{array}{c}-.12 \\
(-1.62)\end{array}$ & $\begin{array}{r}-.23 * \\
(-1.77)\end{array}$ & $\begin{array}{l}-.08 \\
(-.84)\end{array}$ \\
\hline $\begin{array}{l}\text { IDEAL ACE*FIN. RESOURCES } \\
\text { INTERACTION (THOUSANDS) }\end{array}$ & $(-1.68)$ & $\begin{array}{r}-.001 \\
(-.42)\end{array}$ & $\begin{array}{l}-.0005 \\
(-.19)\end{array}$ & $(-1.91)$ \\
\hline $\begin{array}{l}\text { CHI - SQUARE } \\
\text { (d.f.) }\end{array}$ & $\begin{array}{l}39 * * * \\
(11)\end{array}$ & $\begin{array}{l}41 * * * \\
\text { (11) }\end{array}$ & $\begin{array}{l}53 * * * \\
(11)\end{array}$ & $\begin{array}{l}65 * * * \\
\text { (11) }\end{array}$ \\
\hline B. Effects of Ideal Age* & ge Interact & Ions on the & robabil1ty & of Marrying \\
\hline $\begin{array}{l}\text { FINANCIAL RESOURCES } \\
\text { (THOUSANDS) }\end{array}$ & $\begin{array}{r}-.005 \\
(-.87)\end{array}$ & $(-2.15)$ & $\begin{array}{r}-.007 \\
(-.99)\end{array}$ & $\begin{array}{l}-.011 \star \\
(-1.99)\end{array}$ \\
\hline $\begin{array}{l}\text { CHILD'S } \\
\text { AGE }\end{array}$ & $\begin{array}{l}-.19 \\
(-1.85)\end{array}$ & $\begin{array}{c}-.22 \\
(-2.09)\end{array}$ & $\begin{array}{l}-.10 \\
(-.65)\end{array}$ & $\begin{array}{l}-.19 \\
(-1.21)\end{array}$ \\
\hline $\begin{array}{l}\text { MOTHER'S } \\
\text { IDEAL AGE }\end{array}$ & $\begin{array}{l}-.77 * * * \\
(-3.59)\end{array}$ & $\begin{array}{l}-.83 * * \star \\
(-3.88)\end{array}$ & $\begin{array}{r}-.65 * \\
(-2.24)\end{array}$ & $\begin{array}{l}-.81 * * \\
(-2.86)\end{array}$ \\
\hline $\begin{array}{l}\text { AGE*IDEAL AGE } \\
\text { INTERACTION }\end{array}$ & $(3.00)$ & $\begin{array}{l}.05 * * * \\
(3.26)\end{array}$ & $\begin{array}{l}.03 \\
(1.43)\end{array}$ & $(2.13)$ \\
\hline $\begin{array}{l}\text { CHI - SQUARE } \\
\text { (d.f.) }\end{array}$ & $\begin{array}{l}45 * * * \\
(11)\end{array}$ & $\begin{array}{l}51 * * * \\
\text { (11) }\end{array}$ & $\begin{array}{l}55 * * \\
\text { (11) }\end{array}$ & $\begin{array}{r}66 * * * \\
\text { (11) }\end{array}$ \\
\hline$* P<.05$ & $* * P<.01$ & $\star \star \star \quad P<.001$ & ONE-TAIL & \\
\hline
\end{tabular}

a Each of the models estimated here also includes controls for the same measures of parental education, mother's total children, mother's premarital pregnancy, mother's age at marriage, and mother's experiences with widowhood, divorce, and remarriage as used in previous models. The models displayed here are based on analyses of the same number of person-periods as the corresponding models in Table 5 .

both the income and the assets specifications of the model, but only in the assets model among sons. The positive effect of the interaction reduces the negative effect of mothers' ideal age more and more as the individual ages. This effect is consistent with the interpretation that mothers' ideal age for their children's marriages has a negative effect on the probability of marrying, delaying the transition to marriage, but that this effect weakens as children age. The delaying effect of mother's ideal age might weaken 
because children become more mature and independent with age, possibly reducing the amount of influence parents are able to exert over their children's marriage plans.

The fact that parents' ideal ages for their children to marry was measured only once, in 1980, is of some concern for the conclusion that this effect dissipates as children mature. The distribution of parental ideal ages for their children to marry probably changes as their children age. Therefore, it is likely that as the years pass, the 1980 measure bccomcs less and less accurate as an indicator of parental preferences at the time the children are at risk. This measurement problem may produce the weakening of the influence of parents' ideal age observed in the data.

\section{CONCLUSION}

This paper addresses the nature of the influence of parental resources on the entrance into marriage. We examine empirical predictions generated by hypotheses focusing on the home environment, the development of consumption aspirations, the educational process, parental preferences, and parental manipulation of children's behavior. We differentiate between parental financial resources, which can be used directly to manipulate the alternatives available to children, and parental nonfinancial resources, which cannot. Our consideration of how the effects of parental resources might depend upon parental preferences leads us to arguc that the age parents think is best for their children to marry should be taken directly into account. Finally, we proposed that the influence of the parents' stated ideal age for their children to marry on the probability their children marry in any given period decreases as children become older.

Our findings provide some support for each of the causal mechanisms considered, with each having some merits in explaining the influence of parental resources on marital timing. Parents' financial resources and parents' educational attainment both have significant additive delaying effects on the timing of marriage. Mothers' ideal ages for their children to marry also have a delaying effect on the timing of marriage. Our evidence is also somewhat consistent with the conclusion that parents use their resources to manipulate the timing of their children's marriages to correspond to the parents' preferences. Thus, we find that each of the causal mechanisms considered contributes to our understanding of the intergenerational influences on the timing of marriage.

The delaying effect of parents' financial resources is consistent with the hypothesis which predicts that individuals will maximize their utility by staying longer in a wealthy home environment than in a less wealthy home environment. The financial resource effect is also consistent with the hypothesis which predicts that children growing up with wealthy parents form higher consumption aspirations and delay marriage in order to achieve higher levels of consumption before marriage. Finally, the finan- 
cial resource effect is consistent with a hypothesis focusing on the greater access to educational experience and materials which wealth can provide and the delaying effect of educational enrollment on marriage. Our data do not allow us to evaluate the relative merits of these three interpretations, and the next step in building a model of these effects is to include explicit measures of the mechanisms these three hypotheses imply. Our results suggest that the search for specific mechanisms should start from an examination of parental financial assets, not parental income, since assets had stronger effects than income in the additive models.

There are a number of causal mechanisms through which the parental education effect might operate. Goldscheider and Waite (1986) suggested that parental education may affect an individual's position in the marriage market. There is also evidence that parents' educational attainment influences the amount of education children desire to attain (Marini, 1978). These aspirations for education may be translated into extended enrollment in colleges and universities which delay marriage. We find some support for this possibility in that the delaying influence of parental education appears to dissipate as children get older, since at older ages the amount of school enrollment diminishes.

Parental educational attainment may also influence individuals' attitudes about the importance or the nature of an occupation as a pursuit which competes with marriage. Such attitudes about work have been shown to influence the timing of marriage (Cherlin, 1980). Parents' education may also influence children's aspirations for marriage and the formation of a family by modifying assumptions about the prerequisites for entering a marital relationship. Analytically, the next steps in developing this model of parental influence on the transition to marriage involves explicitly including intervening factors through which this parental nonfinancial resource may operate.

Our findings support the hypothesis that the older a mother's ideal age for her child to marry, the more her child postpones marriage. Support is also provided for the idea that parental resources, such as educational attainment and income, influence the parents' ideal age for their children to marry.

These results establish parents' ideal age for their children to marry as an important influence on the timing of their children's transition to marriage. Though this study does not have direct evidence of the possible intervening factors linking parents' ideal age to children's behavior, it is likely that there are several such mechanisms. For instance, parents' ideal age probably influences the children's formation of their own attitudes and aspirations regarding the transition to marriage and the timing of this transition relative to other elements of the transition to adulthood. Parents' ideal age for their children to marry may, in part, shape their chil- 
dren's hierarchy of goals as children pass through the life course making decisions.

Our evidence that the influence of parents' ideal age dissipates as children grow older points to the conclusion that increasing maturity and independence may reduce the influence parents' are able to exert on their children. This conclusion must be tempered with caution because the analysis depends on a single measure of parents' ideal age. Nonetheless, the finding suggests that studies of parents' influence on their children should take an approach that acknowledges the potential of that influence weakening as children pass through the life course.

Finally, our evidence provides some support for the conclusion that parents' financial resources interact with their preferences to affect the timing of their children's marriages. This implies that the higher parents' ideal ages for their children to marry, the later those children marry, and the more financial resources parents' have, the more successful they are in influencing the timing of those marriages toward their goals. That is, parents use their financial resources to manipulate the timing of their children's marriage to match parents' preferences. The next step for future work on these intergenerational effects on the timing of marriage is to explore the mechanisms through which parents' use their financial resources to manipulate the alternatives available to children and children's decisions to marry.

\section{REFERENCES}

Allison, P. D. (1982). "Discrete-time methods for the analysis of event histories," in Sociological Methodology (S. Leinhart, Ed.), Jossey-Bass, San Francisco.

Allison, P. D. (1984). Event History Analysis: Regression for Longitudinal Event Data, Sage Publications, Beverly Hills.

Alwin, D. F., and Thornton, A. (1984). "Family origins and the schooling process: Early versus late influence of parental characteristics," American Sociological Review 49, 784-802.

Bayer, A. E. (1969). "Life plans and marriage age: An application of path analysis," Journal of Marriage and the Family 31, 551-558.

Bongaarts, J. (1982). "The fertility inhibiting effects of the intermediate fertility variables," Studies in Family Planning 13(6-7), 179-189.

Cherlin, A. (1980). "Postponing marriage: The influence of young women's work expectations," Journal of Marriage and the Family 42, 355-376.

Cherlin, A. (1981). Marriage, Divorce, Remarriage, Harvard Univ. Press, Cambridge.

Easterlin, R. (1980). Birth and Fortune, Basic Books, New York.

Elder, G. H., and Rockwell, R. C. (1976). "Marital timing in women's life patterns," Journal of Family History 1, 34-53.

Freedman, D. S., Thornton, A., and Camburn, D. (1980). "Maintaining response rates in longitudinal studies," Sociological Methods and Research 9, 87-98.

Freedman, D., Thornton, A., Camburn, D., Alwin, D., and Young-DeMarco, L. (1988). "The life history calendar: A technique for collecting retrospective data," Sociological Methodology 18, 37-68. 
Goldscheider, C., and Goldscheider, F. K. (1987). "Moving out and marriage: What do young adults expect?" American Sociological Review 52, 278-285.

Goldscheider, F. K., and Waite, L. J. (1986). "Sex differences in the entry into marriage," American Journal of Sociology 92, 91-109.

Hirschman, C. (1985). "Premarital socioeconomic roles and the timing of family formation: A comparative study of five Asian societies," Demography 22, 35-59.

Hogan, D. (1978). "The variable order of events in the life course," American Sociological Review 43, 573-586.

Kmenta, J. (1986). Elements of Econometrics, 2nd ed., Macmillan, New York.

Kobrin, F. E., and Waite, L. J. (1984). "Effects of childhood family structure on the transition to marriage," Journal of Marriage and the Family 46, 807-816.

Maddala, G. S. (1983). Limited-Dependent and Qualitative Variables in Econometrics, Cambridge Univ. Press, New York.

Malthus, T. R. (1986). "An essay on the principle of population," in Thomas Malthus: An Essay on the Principle of Population (A. Flew, Ed.), Penguin, New York.

Marini, M. M. (1978). "The transition to adulthood: Sex differences in educational attainment and age at marriage," American Sociological Review 43, 483-507.

Marini, M. M. (1984). "Age sequencing norms in the transition to adulthood," Social Forces 63, 229-244.

McLanahan, S., and Bumpass, L. (1988). "Intergenerational consequences of family disruption," American Journal of Sociology 94, 130-152.

Modell, J. (1980). "Normative aspects of American marriage timing since World War II," Journal of Family History 5, 210-234.

Morgan, S. P., and Teachman, J. D. (1989). "Logistic regression: Description, examples, and comparisons," Journal of Marriage and the Family 50, 929-936.

Peterson, T. (1986). "Estimating fully parametric hazard rate models with time-dependent covariates: Use of maximum likelihood," Sociological Methods and Research 14, 219246.

Preston, S. H., and Richards, A. T. (1975). "The influence of women's work opportunities on marriage rates," Demography 12, 209-222.

Rindfuss, R. R. (1991). "The young adult years: Diversity, structural change, and fertility," Demography 28(4), 493-512.

Rodgers, W. L., and Thornton, A. (1985). "Changing patterns of first marriage in the United States," Demography 22, 265-279.

Sewell, W. H., Haller, A. O., and Portes, A. (1969). "The educational and early occupational attainment process: Replication and revision," American Sociological Review 34, 82-92.

Sewell, W. H., and Hauser, R. M. (1975). Education, Occupation and Earnings: Achievement in the Early Career, Academic Press, New York.

Sewell, W. H., Hauser, R. M., and Wolf, W. C. (1980). "Sex, schooling and occupational status," American Journal of Sociology 86, 551-583.

Thornton, A. (1988). "Cohabitation and marriage in the 1980s," Demography 25, 497-508.

Thornton, A. (1991). "Influence of the marital history of parents on the marital and cohabitational experiences of children," American Journal of Sociology 96(4), 868-894.

Thornton, A., and Freedman, D. (1982). "Changing attitudes towards marriage and single life," Family Planning Perspectives 14, 297-303.

Thornton, A., and Freedman, D. (1983). "The changing American family," Population Bulletin 38, 1-44.

Thornton, A., Freedman, D. S., and Camburn, D. (1982). "Obtaining respondent cooperation in family panel studies," Sociological Methods and Research 11, 33-51.

Thornton, A., and Rodgers, W. L. (1987). "The influence of individual and historical time on marital dissolution," Demography 24, 1-22. 
Thornton, A., Axinn, W., and Teachman, J. (1992). The Influences of Educational Aspirations and Experiences on Entrances into Cohabitation and Marriage, unpublished paper, Survey Research Center, Institute for Social Research, The University of Michigan, Ann Arbor.

Waite, L. J., Goldscheider, F. K., and Witsberger, C. (1986). "Nonfamily living and the erosion of traditional family orientations among young adults," American Sociological Review 51, 541-554.

Waite, L. J., and Spitze, G. D. (1981). "Young women's transition to marriage," Demography 18, 681-694. 